EINO KROH N

\title{
Graal-taru suomalaisessa runoudessa
}

Pyhän Graalin taru, jonka legendaaristen ja myytillisten ainesten alkuperä katoaa hämärään menneisyyteen, on monien vuosisatojen aikana lumonnut ihmisten mielet. Keskiaikaiseen ritariromantiikkaan liittyneenä se levisi yli koko Euroopan. Alkuaan Englannista kotoisin olevat kertomukset Arthur-kuninkaasta ja hänen pyöreän pöytänsä ympärille kerääntyvistä ritareista saivat syvästi uskonnollis-vertauskuvallisen värityksen, kun niiden kirjalliset esittäjät, joku Christien de Troyer tai Robert de Boro Ranskassa tai joku Wolfram v. Eschenbach Saksassa tekivät pyhästä Graalista seikkailevien ritarien korkeimman päämäärän.

Graalia vartioi korkealle vuorelle rakennetussa, loistavassa Montsalvatin linnassa pyhä ritarikunta kuninkaansa johdolla. Mutta vain henkisesti kyllin kehittyneet yksilöt, puhdassydämiset saivat armon päästä tähän linnaan tullakseen osallisiksi Graalin ihmeitä tekevästä voimasta. Graal oli erään käsityksen mukaan se malja, josta Kristus opetuslapsineen nautti viimeisen ehtoollisen ja johon Josef Arimatialainen oli kerännyt ristiinnaulitun Jeesuksen haavoista vuotaneen veren. Tällä valkohohtoisesta kullasta ja jalokivestä tehdyllä maljalla oli jumalallinen voima. Se antoi terveyden jà kuolemattomuuden, ikuisen elämän. Toísen selityksen mukaan Graal oli merkillinen ennustava jalokivi, joka tulikirjaimin ilmoitti, keistä oli tuleva kuninkaita, ja joka myös antoi elämän voiman. Pitkäperjantaina kyyhkynen laskeutui sen luo asettaen sille pyhän, valkohohteisen ehtoollisleivän, oblaatin.

Vaikkakin Graal keskiaikaisessa mielikuvituksessa todennäköisesti käsitettiin todella aineelliseksi, pyhäksi ihme-esineeksi, oli sillä epäilemättä jo silloin myös vertauskuvallinen merkitys. Molemmat selitykset, malja-aihe ja jalokivi-aihe, viittasivat ehtoollismysteeriin, jossa ihminen pääsi yhteyteen Kristuksen ikuisen elämän kanssa. 
Se oli siten väline ja keino, joka sai aikaan tietyn tajunnan muutoksen, hurmioituneen vaipumisen tosiolevaisen näkemiseen. Siveellinen harhaileminen ja etsiminen, joidenkin kokeiden läpäiseminen ja sitten Graalin löytäminen ovat asteita jumalallisen kirkastumisen tiellä. Toisaalta ei Graal ilmeisestikään symbolisoi ainoastaan jumaluuteen nousemista, vaan kohoaa vertauskuvaksi itse jumalallisesta perikuvasta, logoksesta tai kristillisen mystiikan kielelle käännettynä Kristuksesta.

Wolfram v. Eschenbachin "Parzival"-runoelmassa on kohtia, jotka osoittavat, ettei Graalin kaipuu kohdistu vain jonkin ihmeesineen löytämiseen, vaan itse siihen jumalallisen elämän lahjoittamaan autuaalliseen tilaan, jota Graal merkitsee. Sen tähden Parsifal, joka kerran on saanut esimakua Graalista, tuntee raskasta tuskaa eikä voi tulla onnelliseksi, ennen kuin on voittanut Graalin:

Dahin zielt meines Herzens Drang, Sitä sydämeni kaipaa, siihen dahin will ich mein ganzes Leben tahdon koko elämäni ajan kaikmit allen meinen Sinnen streben. Kine aisteineni pyrkiä.

Eschenbachin runoelma antaa myös hyvän käsityksen siitä, miten eri aiheet sulautuvat yhteen tässä ritariromantiikassa. Paikoitellen on vaikea erottaa Graalin palvontaa naisen palvonnasta. Niiden tosiasiallinen kohde onkin sama. Niinpä Parsifal helluntain ajoissa näkee kolme pisaraa linnun verta valkoisella lumella. Nähdessään nämä veripisarat hän muistaa kaipaamaansa vaimoaan, Kondviramuria, ja vaipuu niin syvään halttiotilaan, ettei edes huomaa hyökkääviä ritareita. Ja runoilija sanoo hänestä:

Das Ebenbild der Königin, sein stilles Trachten nach dem Gral beschwerten leidvoll seinen Sinn.
Kuningattaren vertauskuva ja hänen hiljainen Graalin kaipuunsa painoivat tuskallisesti hänen mieltään.

Sitten Gawan huomaa veripisarat ja arvaa, että Parsifal on minne-tunteen vallassa. Tässä siis kuningattaren vertauskuva samalla herättää hänessä Graalin kaipuun. Näyttää yleensäkin siltä, että puhtaan ja epäitsekkään naisen rakkauden voittaminen on eräs välttämätön esivaihe Graalin löytämisessä. Tällainen käsitys on periytynyt Volter Kilven paljon myöhäisempään Graalin tulkintaan. 
On luonnollista, että se keskitetty ja kirkastunut vertauskuvallisuus, joka liittyy tähän taruun, ja se lumoava salaperäisyys, johon. se kietoutui, oli omiaan antamaan herätteitä myös myöhemmän ajan runolliselle mielikuvitukselle. Graalista on siten tullut merkittävä. taiteellis-kirjallinen aihe, jota runoilijat Suomessakin ovat kehitelleet omien uskonnollisten ja elämänymmärrykssellisten näkemystensä. pohjalta.

Keskiaikaisia esikuvia on kenties uskollisimmin seurannut englantilainen runoilija Alfred Tennyson kertoessaan runoelmateoksessaan "Idylls of the King" Arthur kuninkaan ritareista. Eräässä: näihin kertomuksiin liittyvässä laajassa runossa hän myös kuvaa. Graalin etsintää. Siinä Parsifal, se Arthurin ritari, jota sanottiin puhtaaksi ja joka oli vetäytynyt luostarin rauhaan, kertoo eräällemunkkiystävälleen Graalista. Sysäyksen Graalin etsimiseen oli antanut Parsifalin sisar, joka pitkäaikaisen paaston ja rukouksen jälkeen oli saanut nähdä Graalin maljan laskeutuvan luokseen kammioonsa pitkin hopeista sädettä. Oman uskonsa hän herätti rakastetussaan, ritari Galahadissa, joka päätti vihkiä elämänsä Graalin etsintään. Kerran tapahtui ihme. Graal laskeutui Arthur-kuninkaan saliin, johon ritarit olivat kokoontuneina. Ja vaikka vain Galahad' todella näki sen, havaitsivat muutkin siihen liittyvän valoilmiön ja. äänen; ja näyn järkyttäminä useat ritarit vannoivat, että etsisivät vain Graalia vuoden ajan.

Tennyson kuvaa sitten, miten näiden ritareiden salaisimmatkin heikkoudet, heidän ylpeytensä, kärsimättömyytensä, maallinen huolenpitonsa jne. muodostuvat esteiksi heidän tiellään. Ja he joutuvat monenlaisiin kokeisiin, näkyjen ja harhakuvien valtaan. Vain: Galahadin onnistuu päästä Montsalvatin linnaan Graal-ritariksi, sillä hänellä on kykv pelastaa itsensä, sielunsa, menettämällä itsensä. Hän siis seuraa Kristuksen itseuhrin käskyä.

Tunnetuimmaksi on epäilemättä meidän aikanamme tehnyt Graal-. tarun Richard Wagner oopperallaan 'Parsifal", jonka tekstin säveltäjä itse on kirjoittanut. Hänellekin Graal on ihmemalja, jonka vaikutustehon säilyminen on ihmiskunnalle elintärkeä asia. Mutta: Graalin vartija, Amfortas, on langennut. Haavoitettuna hän vääntelehtii tuskissaan menetettyään yhteytensä Graaliin. Graal on suljetussa lippaassa, eikä siihen liittyvää ehtoollismysteeriä enää tapahdu. Montsalvatiin saapu silloin puhdassydäminen Parsifal 
murıettuaan viettelevän itsekkyyden taikakehän, jota edustaa Klingsoi-noidan linna. Parsifalin läsnäollessa Graalin ihme jälleen tapahtuu.

Graal-aiheen innoittama on myös toinen Wagnerin ooppera, Lohengrin.

Omintakeisen syvällisellä tavalla on Graal-aihetta käsitellyt Gustaf Fröding runossaan "Graalin satu". Graal esitetään siinä kaiken olemassaolon toivona ja lohdutuksena, ihmeellisesti hohtavana jalokivenä, viisasten kivenä. Se oli muinoin smaragdinen malja, josta elämän viini oli vuotanut yli. Mutta nyt malja on sulkenut juoman sisäänsä, ja viinistä on tullut rubiinia. Smaragdi ja rubiini, vihreä ja punainen, toivon ja rakkauden värit.

Kuten huomaamme Fröding on yhdistänyt molemmat keskiaikaiset Graalin kuvaukset yhdeksi ainoaksi vaikuttavaksi symboliksi. Hänelle Graal ei ole enää vain kristillinen symboli ehtoollisesta, vaan eheyttävä ja elähdyttävä jumalallinen henki kaiken takana. Hänen Graal-ritarissaan, joka on sekä Jumalan että Saatanan rakastama ja joka voittaa rakkauden urotyöllä taivaan vihan tuomittuja kolıtaan, on demonista voimaa. Sankari, joka pystyy syleilemään kaikkea, on oikea mies. Hän voi löytää smaragdiastiaan kätketyn viinin.

Runosikermässään "Gral-stänk", Graalin vihmaa, Fröding palaa uudelleen tähän aiheeseen ja samalla käsitykseen Graalin kaikkiallisesta luonteesta olemassaolon jumalallisena alkuvoimana. Kukaan ei tiedä, missä Graal on, mutta syvimpänä olioissa on kipinöitä siitä valosta, jota oli elämänjuomassa. Näitä kipinöitä, tätä Graalin vihmaa on kaikissa elämän ilmiöissä, näköjään alhaisimmissakin.

Vuosisatamme alkupuolen suomenkielisessäkin runoudessa Graalaïhe alkaa esiintyä. Luulisi Eino Leinon tarttuneen tähän runokuvaan, joka tuntuisi olleen läheinen hänen mystiikalleen. Näin ei ole kuitenkaan tapahtunut. Mutta Leinon piiriin läheisesti kuuluvalla L. Onervalla on "Graalin malja"-niminen runo kokoelmassaan "Elämän muukalainen". (1921).

Onerva oli vuosisadan alussa edustanut varsin realistista ja sensualistista suuntaa. Sitä oli vahvistanut Friedrich Nietzschen merkittävä vaikutus, joka näkÿy sen ajan monien huomattavimpien runoilijoiden tuotannossa. Onervallakin oli nietzscheläinen kautensa, kuten Leinolla, Koudalla, Kilvellä, Södergranilla ym. Oppi yli-ihmi- 
sestä, joka on tuolla puolen hyvän ja pahan ja jolla on täydellinen oikeus yksilölliseen itsetoteutukseen, lienee se nietzscheläinen oppi, joka on tehnyt syvimmän vaikutuksen ja joka selvästi heijastuu myös Onervan runoudessa.

Ensimmäisen maailmansodan aikoina tapahtui kuitenkin yleinen käänne. Entiset nietzscheläiset kääntyivät persoonallisuuden palvonnasta romantiikkaan. Tyypillisimpiä esimerkkejä tästä ovat juuri Onerva, Leino, Kouta ja Kilpi. Kokoelmasta "Kaukainen kevät" (1914) saakka tämä. kääntymys leimaa Onervan runoutta, joka saa vahvasti kristillisiä piirteitä juuri "Elämän muukalaisessa". Graalin ulkonaiseen olemukseen sisältyy Onervan kuvauksen mukaan samoja piirteitä, jotka tunnemme keskiaikaisista esikuvista:

On pyhä lipas jossain, malja Graalin, heljempi päivää, tulta timantin.

Sen Kristus huuhtoi verikyynelin, kun horjui vaaka Jumalan ja Baalin.

Tässä on sekä malja- että jalokiviaihe ja myös kristillinen ehtoollissymboli. Graal-symbolin tulkinta tässä runossa osoittaa, miten täydellinen runoilijan sisäinen muutos on ollut. Entinen ihanne on kääntynyt vastakohdakseen, nietzscheläinen persoonallisuuden itsetoteutus on vaihtunut itseuhriksi, itsensä menettämiseksi. Synkín värein Onerva kuvaa sitä itsekkyyden myrkyllistä maailmaa, jossa ihmiskunta elää ja josta vain Graalin ihme voi pelastaa. Kohtalokasta olisi, jos pahuuden valta pääsisi täysin tyrehdyttämään Graalin maljasta tulvehtivat viinin lähteet, niin että tuo kristallimalja ikuisiksi ajoiksi jäisi tyhjäksi. Runon loppusäkeet osoittavat kuitenkin, että runoilija uskoo Graal-voimiin, jotka valvovat korkeamman maailmanjärjestyksen toteutumista:

Iäti säilyy syy ja syyttömyys ylinnä ylväs itse-uhrin mahti. Salaisuus yksilön - mut valtain vahti on Graalin maljan pyhä kyynelvuo.

Volter Kilven varhaistuotannossa on hänen romanttiskoristeelliselle tyylilleen ominainen suorasanainen "Parsifal"'-niminen Graalrunoelma. Se on hartaan ja hurmioituneen mystiikan läpäisemä, ja 
siinä erotturat selvästi perinteellisen Graalin opin keskeiset periaatteet:

"Graalin temppeli hiljaisessa puistossa on puhtauden Temppeli, ja sen korkeassa kuorissa polvistuu puhtauden pappi, Graalin ylhäinen kuningas, Graalin pyhän maljan edessä."

Kilpi on käyttänyt, kuten Wagner, Amfortas-aihetta osoittaakseen, miten Graalin teho vahvistuu samassa suhteessa, kuin arvokkaat yksilöt uhraavat sille koko henkisen olemuksensa voiman jättäen taakseen persoonalliset, itsekkäät siteensä, mutta kuinka se myös heikkenee kannattavan yksilöllisen voiman puutteessa. Yksilön kosmillisessa mielessä innostava, henkisiä voimia vapauttava merkitys tulee tässä selvästi ilmi.

"Graalin pyhän maljan edessä tulvii nimittäin puhdas ja syvä palavahenkinen ihminen maailman liikutussydämeksi ja valaisee ihanan ilon heijastuksena maailmaa", Volter Kilpi kirjoittaa.

Tämä yksilön laajentuminen kosmilliseksi, maailman kaikkeudelliseksi tekijäksi näkyy myös seuraavasta otteesta:

"Graal, jonka malja tulvehtii tulvivarintaisen ikuisuuden edessä. Graal, jossa syvälaineisin ihminen lainehtii maailman sydämessä. Parsifalin sydän kasvaa. Graaliin on hänen mielensä."

Täyttymykseen sisältyy kuitenkin itseuhri, ahtaamman persoonallisen minän kuolema, kuten Tennysonilla ja Onervalla.

"Parsifal ja Konviramus Graalin pyhän maljan edessä. Iäisyysihanaa on polvistua Graalin pyhän maljan edessä, sydän maailmaksi kasvavana, itsestään kuolevana. Eikö kuolekin jokaisesta värähdyksestä, jonka sydämessään tuntee. Mahtuuko maailmassa olemaankaan muuta värähdystä kuin iäisessä hetkessä sydämen lävitse värjyvä liikutus."

Huomaamme, että tässä ilmeisesti on kysymys tietystä kosmisesta hengen tilasta, että vanha keskiaikainen kristilliseen mystiikkaan kätkeytynyt logos-käsitys tässä toistuu.

Aarni Koudan ruusuristiläisessä kokoelmassa "Ristin tie" (1922) "Graalin malja" on avausrunona. Sekin rakentuu kristilliseen mystiikkaan, jonka mukaan Graal edustaa ihmișessä heräävää jumalallista Kristus-voimaa:

Elämään iankaikkiseen silmät se avaa, sen eess' oman itsensä tuntohon havaa. 
Epäpuhdas sen liekkejä nähdä ei saata, hän maasta on tullut ja etsii maata.

Ketä ei voi koskettaa elon saasta, ylös taivaille taasen hän nousevi maasta.

Hänen sielussaan tuli Graalin palaa, pyhän maljan tuo sydämeensä hän salaa.

Malja ja jalokivivaihe ovat yhtyneet yhdeksi myös Lauri Pohjanpään "Graalin malja"-kokoelman Graal-runossa :

Ja malja jaspikivinen

on kallein aarre linnan sen.

Jo pelkästään Graalin linna merkitsee Pohjanpään runossa sitä ihmisen sisäistä henkistä tilaa, jossa hyvyys hallitsee:

Se luonas on ja ympärilläs.

Se on syvällä, syvällä itsessäs.

Mutta Klingsor-noidan loihdut on ensin voitettava:

Paha voita, ja loihdut laukeaa, pyhän Graalin portit aukeaa.

Paha voita omassa rinnassas, pyhän Graalin malja on huulillas.

Ja runon loppusäkeissä korostetaan, kuten Koudankin vastaavassa runossa, puhtauden merkitystä :

Pyhä Graal - Elon Kauneus ihana on vain sen, kenen sydän on tahraton.

Viittaus uuden testamentin eetilliseen julistukseen on tässä, kuten keskiaikaisessakin Graal-runoudessa ilmeinen: "Autuaat ovat puhdassydämiset, sillä he saavat nähdä Jumalan." (Matt. 5:8.)

Kaipaus on kaikkina aikoina kuulunut romanttisen aatevirtauksen perustuntoihin. Väkevänä tunnevireenä se liittyy jo ritariromantiikan Graalin etsintään. Sama kaipaus väreilee Arvi Kivi- 
maan Graal-runossa, kaipaus kauaksi ja korkealle, vuorelle, luoksepääsemättömään Montsalvatin linnaan, toiseen, henkiseen tajunnantilaan.

Maan vanki on ruumiini. Pääse en kahleesta tästä.

Kaipausteiden lintu sieluni on.

Kauas se nousee kirkkauteen elämästä

etsien uusia teitä äärellä auringon.

Rujo ruumiini on, niin hauras ja murtuva kuori.

Seuraa uupuvin silmin nousua sen.

Loitos, loitos! Jossakin on pyhä vuori,

Jossakin Graalin malja ihmeellinen.

Sieluni lintu kerran on pääsevä sinne

Uupuen maljaan välkkyvän kristalliseen.

Tyynenä katsoo se: on kukkiva taivaan rinne.

Tähdet hohtavat, Maahan, ihmisen pimeyteen.

\section{Fino Krohn: The Grail Legend in Finnish Poetry}

The writer first summarises the Grail Legend, the quest for the magic bowl or jewel guarded by the Knights of the Grail. The knights errant of medieval romances search for the bowl as the greatest treasure in the world. The writer tries to show how the theme has come to be a symbol in Christian. mysticism regarding the Logos and the mystery of the Holy Communion. Then the recurrence of the theme in later literature is discussed (Tennyson, Wagner and Fröding). In Finnish literature, the Grail is a subject especially attractive to the poets under the sensualist influence of Nietzsche. The Grail poems belong to the period of their later conversion to romanticism and Christian mysticism. The poems of Volter Kilpi, L. Onerva and Aarni Kouta are analysed along these lines. Pohjanpää's anthology 'The Bowl of the Grail' and the poem. of the Grail included in it are based on general. Christian beliefs. In Arvi Kivimaa's poem of the Grail, the central theme is a romantic longing for a higher spiritual existence that is symbolised by the Grail. The writer comes to the conclusion that although various poets have developed the subject according to their individual views of life, the outward symbols of the story, the bowl and the jewel, and the inner ideology are in essence the same as their medieval models. 